\title{
A feverish imagination
}

\section{Poems, plays and novels punctuated the life of Ronald Ross.}

\section{Martin Kemp}

There was more to Ronald Ross (1857-1932) than his Nobel Prize for discovering the role of the Anopheles mosquito in the transmission of malaria. Ross's Memoirs paint a picture of a driven man, intolerant of petty-minded administrators, whose inner life was coloured by a vivid literary and artistic imagination.

Ross' father had thwarted his initial ambitions to become an artist. Subsequently, a series of deeply felt poems, plays and novels punctuated his working life as a doctor specializing in tropical medicine. An admirer of the full-blooded romanticism of Lord Byron and Alfred Lord Tennyson, and a friend of John Masefield (the later poet laureate), Ross was also drawn at an early age to Johann Wolfgang von Goethe's Faust, as a skilled drawing in his teenage sketchbook from 1872 testifies.

Much of the sketchbook is occupied by accomplished landscape drawings and watercolours made on the Isle of Wight, perhaps with the assistance of a camera lucida. An annotation in the sketchbook records the source of Ross's drawing of Faust as Moritz Retzsch's 27 illustrations of Goethe's tragedy, first published in Britain in 1820. However, this is true only in a generic sense, because Ross's drawing does not correspond directly to any of the Retzsch prints but seems to be his own imaginative variation on the theme. Faust sits brooding in a lansdcape, while an owl, a symbol of night, hovers nearby. The demeanour of Faust manifests the devilish melancholy that traditionally afflicts those who strive towards the ultimate and the unattainable.

Ross's Memoirs, in the period leading up to his discovery, oscillate between hope and despair. Posted in Secunderabad, India, he had himself contracted malaria in April 1897. The monsoon was slow to break. The heat became stifling and the insects intolerable. Working in isolation with feverish intensity, he painstakingly dissected mosquitoes fed on his malariainfected patients. His research was running into a dead end: "failure followed failure". He drafted impassioned lines for his running poetic composition In Exile:

\section{What ails the solitude?}

Is this the Judgement Day?

The sky is as red as blood

The very Rocks decay.

Then, the sudden breakthrough. He dissected mosquito no. 38 without much expectation that it would be different. He observed "some large cells with pigment" in its stomach, no less than nine of them. The note (pictured) is triple underlined. Below some characteristically rapid graphic notations of the kind that punctuate his notes and letters, he records the tell-tale pigments. "The outline of the cells is generally thick, but in the smaller ones sometimes delicate." These were the malaria cells in the mosquito's stomach for which he had been desperately searching. The tone of In Exile transforms:

This day designing God

Hath put into my hand a

Wondrous thing. And God

Be praised. At his command,

I have found thy secret deeds Oh million-murdering Death.

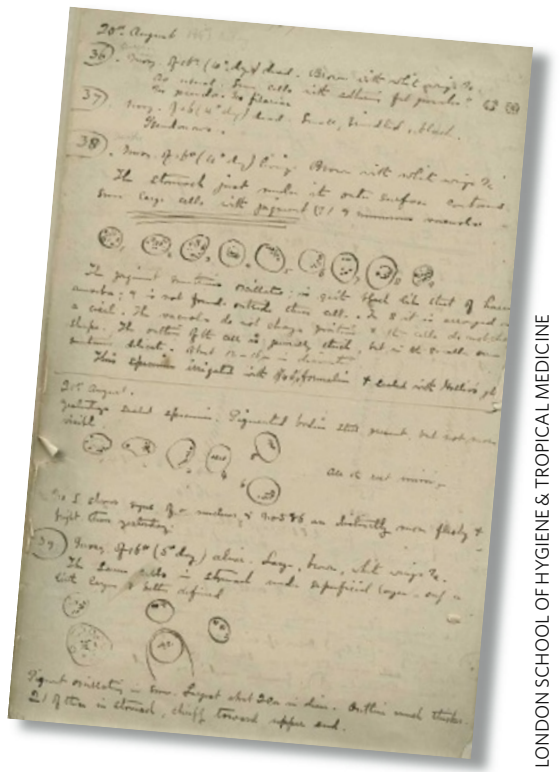

I know this little thing

A myriad of men will save.

O Death. Where is thy sting?

Thy victory, O Grave.

Faust was driven by Mephistopheles, Ross by God. They were well matched in the intensity of their quests. By September, Ross had drafted his urgent official report from India. His regular correspondent and fellow researcher Patrick Manson safeguarded Ross's priority claim by ensuring that his friend's discovery was presented forthwith to the British Medical Association. Two years later Ross was installed in the Liverpool School of Tropical Medicine. The Nobel prize followed in 1902, in the face of formidable competition from Ivan Pavlov, and a knighthood in 1911. Ross was not simply a doctor who wrote poetry; his science and art manifest the imaginative fire that governed his creative life in all its aspects.

Martin Kemp is research professor in the history of art at the University of Oxford, Oxford OX1 1PT, UK.

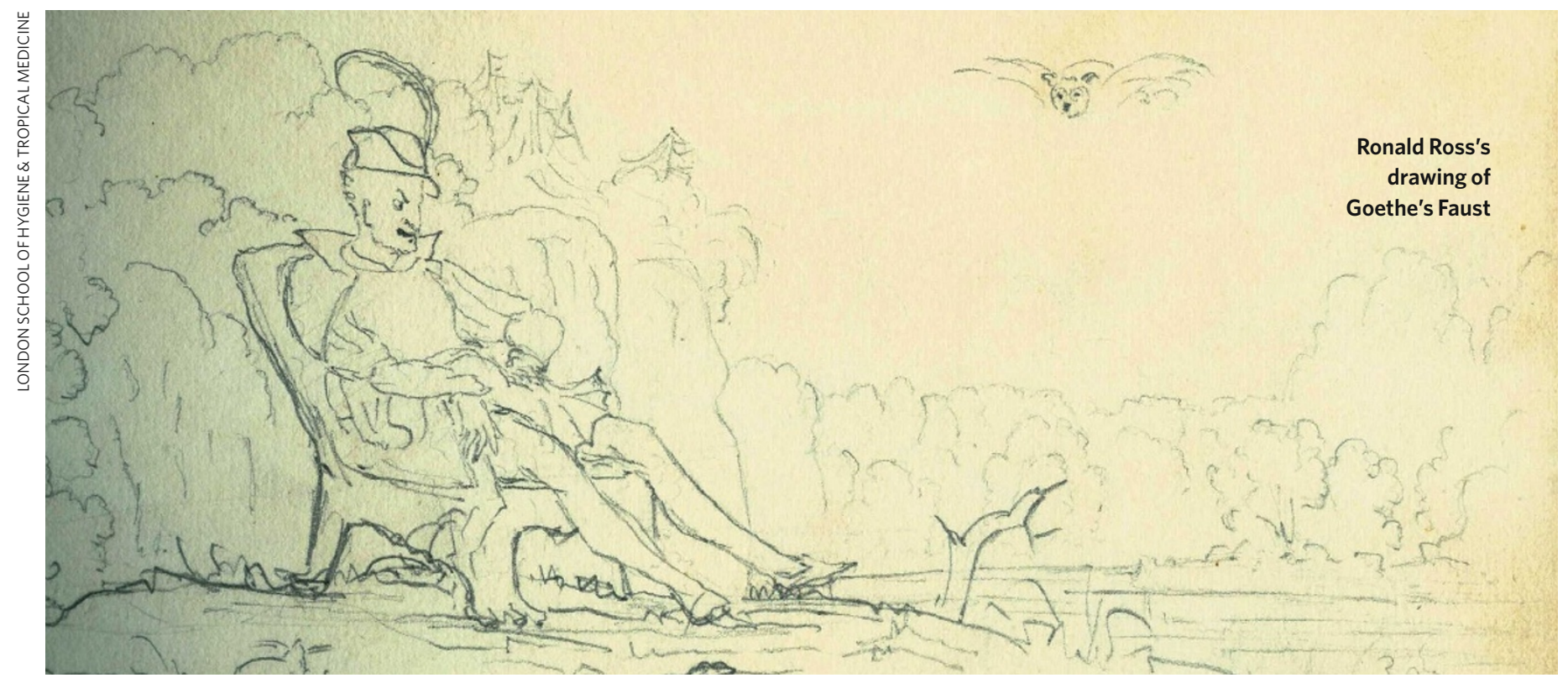

